European Buddhist Traditions

Laurence Cox, National University of Ireland Maynooth

\begin{abstract}
:
This chapter covers those Buddhist traditions which are largely based in Europe, noting some of the specificities of this history as against the North American with which it is sometimes conflated. While the reception history of Buddhism in Europe stretches back to Alexander, Buddhist organization in Europe begins in the later nineteenth century, with the partial exception of indigenous Buddhisms in the Russian Empire. The chapter discusses Asianoriented Buddhisms with a strong European base; European neo-traditionalisms founded by charismatic individuals; explicitly new beginnings; and the broader world of "fuzzy religion" with Buddhist components, including New Age, "night-stand Buddhists", Christian creolizations, secular mindfulness and engaged Buddhism. In general terms European Buddhist traditions reproduce the wider decline of religious institutionalization and boundary formation that shapes much of European religion generally.
\end{abstract}

Keywords: Buddhism, Buddhist modernism, creolization, Europe, immigration, meditation, night-stand Buddhists, Western Buddhism

In 1908, the London investigative weekly Truth hosted a debate between two Burmeseordained European bhikkhus (monks), U Dhammaloka (Laurence Carroll?) and Ananda Metteyya (Allan Bennett). Objecting to newspaper reports presenting the latter, recently arrived in Britain, as the first bhikkhu in Europe, Dhammaloka argued on July $8^{\text {th }}$ that Ananda Metteyya had not been properly ordained, citing the Upasampada-Kammavacana to show that ordinands must state their freedom from various diseases, including asthma (which 
Bennett suffered from). Ananda Metteyya replied on July $15^{\text {th }}$ with a discussion of the Burmese Kammavacana and the Mahavagga and stated that he had believed himself cured at the time of ordination.

The tables were turned in a libel trial brought by a friend of Bennett's against another London scandal sheet, The Looking Glass and reported in The Times for April $27^{\text {th }} 1911$ :

[Mr Schiller, counsel for the publishers]- You had heard that Mr. Dhammaloka had disavowed Mr. Bennett?

[George Cecil Jones, plaintiff]- I read that somebody had written in Truth, in your paper, and this member of the Council of the Buddhist Society of Great Britain and Ireland came to see me. He happened to be a very distinguished chemist. He told me that the Truth thing was nothing at all, it was only that fellow Dhammaloka, nobody takes any notice of him, he was a man who was kicked out, a man whose reputation is just as awful as a man's reputation can be in Burma.

This was not the first time the question of who is an authentic Buddhist was debated in Europe. The first Buddhist missionary to the West, Charles Pfoundes, spent much of his mission (1889 - 92) disputing Annie Besant's claim that Theosophy represented authentic Buddhism, on the basis of his own expertise and experience (Bocking et al. 2014). The Dhammaloka - Ananda Metteyya conflict is, perhaps, the first case where the legitimacy of two competing Buddhist lineages (both had ordained Western followers: Turner et al. 2013) was the subject of press debate and courtroom discussion, fought out both on the London elite's characteristic grounds of class and reputation and on the Burmese sangha's characteristic grounds of vinaya (monastic rules) legality. That the clash occurred at all has to do with both the European prestige of Buddhism and the many different possible claims that can be made for its rightful ownership. 


\section{In this chapter}

As this story shows, even within Europe Buddhist traditions tend to derive some degree of legitimacy from Asian origins and authenticity. Origin claims of various kinds are regularly drawn on across Buddhism to legitimise particular traditions, relating present-day traditions to the Buddha or other figures and relating national traditions to other countries seen as a source of more authentic teachings, a purer sangha, deeper meditative expertise and so on.

The academic study of Buddhism in the West also uses the readily-observable differences between what Buddhism means in the West and in Asia (in terms of who is involved, what they say and what they do) rhetorically, to show the need for specialized study, and heuristically, to identify research questions. Thus an ironic question mark hangs over claims to legitimacy that identify actually-existing Buddhism in the West with Asian authenticity, especially as the development of Buddhist Studies has highlighted the enormous diversity between and within Buddhist traditions and the extent of historical change.

Nonetheless, articulating "European traditions" remains fraught. The Global section of this handbook covers the diffusion of strictly Asian traditions to Europe and elsewhere ${ }^{1}$. In this chapter, "European traditions" are those largely based in Europe. This includes explicitly European, Western etc. organizations; those asserting membership of an Asian-based tradition but de facto centered in Europe in terms of centers, teachers and audience; and those which are not so much concerned at being identified with Europe as resistant to being identified as Buddhist, despite drawing strongly on Buddhist practices and / or doctrines (cf. Baumann 2012, 127). It should be remembered that modernist elements in Buddhism are not necessarily indicative of a Western emphasis; "Buddhist modernism" was primarily developed by Asian Buddhists (McMahan 2008, 22).

It is also important to be open to differences between European and other kinds of Western Buddhism. Much North American, or simply US-based, research generalizes its 
findings to "Western Buddhism", without considering the well-known religious distinctiveness of the US. The proportion of researchers to languages and states; the greater quantity and distribution of US research and the increasing scholarly dominance of English; and the fact that North America made the turn to a focus on meaning and experience rather than philology earlier and more thoroughly than European research (Lopez 1998: 161) - all this leaves research on Buddhism in Europe somewhat in North America's shadow. In considering the development of European Buddhist traditions, factors such as the greater European presence in colonial-period Buddhist Asia, contrasted with the greater Asian Buddhist presence in the Western US during this period, or the different religious and cultural landscapes within which Buddhist ideas were received, have to be borne in mind.

\section{Background history}

The European reception of Buddhism dates back to Alexander's conquests, with transmission of religious doctrines, legendary narratives, travelers' tales, images, ethnographic accounts and translated texts predating any known European conversions, in Europe or Asia (Cox 2013: ch 2). This was followed in the eighteenth and nineteenth centuries by growing philosophical, academic and artistic interest (Almond 1988, Clarke 1997), and increased representation in popular culture, from orientalist novels via museum collections to public exhibitions (Franklin 2008, Cox 2013: ch 3).

These developments were directly linked to intensifying European colonization of Buddhist Asia, leading to far more Europeans encountering Buddhism in Asia (as sailors, soldiers, colonial officials, missionaries, traders and so on); to the development of scholarly Orientalism, tied to the challenge of understanding the cultures being colonized; to the increasing public representation of Asian cultures as part of building popular support for 
imperialism; and to the appearance of Asian Buddhists in Europe, ranging from Ceylonese domestic servants to high-ranking Japanese delegations.

With suitable caveats, Tweed's (2000) three types of American Buddhist can help identify three approaches to Buddhism out of which European traditions also developed: a scholarly, rationalist trend feeding into the formation of learned societies and a concern with doctrinal precision; an aesthetic, romantic appreciation enabling identifications with more culturally-specific forms of Buddhism; and an occult route leading through Theosophy to New Age and to an enthusiasm for ritual and initiation. Although these were never hermetically-sealed, and individuals could draw inspiration from more than one, they did serve to shape the European reception of Buddhism and lay the groundwork for Buddhist organization.

\section{Early history}

The earliest Buddhist groups in Europe represented a variety of attempts to find effective relationships between European organizations and Asian bases. These included Pfoundes' Buddhist Propagation Society (1889 - 92) and Ananda Metteyya's Buddhist Society of Great Britain and Ireland (1907 - 1924), the latter absorbed into the Buddhist Lodge of the Theosophical Society, later the Buddhist Society (Humphreys 1937), while the Maha-Bodhi Society founded a short-lived monastery in London in 1928 (Baumann 2012, 122). In Germany, Karl Seidenstücker's Buddhistische Missionsverein ("Buddhist Mission Society") was founded in 1903 in Leipzig (Baumann 1997, 275) and continued into the 1920s, while Berlin's Buddhistisches Haus ("Buddhist House”, founded 1924) operated until 1941 and was slowly revived from the later 1950s. In 1909-10 the German-born Theravadin monk Nyanatiloka briefly attempted to found a vihara (monastery) in Switzerland (Baumann 2000, 154-5). In Denmark, a Buddhist Society was founded in 1921 (Borup 2008, 29); in Dublin a 
Buddhist center operated from 1927-9 until 1935-6 (Cox 2014a); while Les amis du bouddhisme ("The friends of Buddhism") operated in Paris from 1929 (Baumann 2012, 122).

This list, not exhaustive, shows two tendencies: one attempting to found a (typically Theravadin) bhikkhu-sangha (monastic order) in Europe, the other towards a more laycentered formation, often with a weaker sectarian emphasis. Rarely were the practical problems raised by either approach capable of solution at the time: there were few lay supporters and little understanding of vinaya practicalities, while the public society form, often relying on lectures, lacked a strategy for converting widespread public interest in Buddhism into something better-defined and longer-lasting. What today has become the almost universal solution - adopting meditation or a comparable practice (such as chanting) as a core activity, readily presented in evening classes and not requiring extensive preparation - took a long time to develop. Uncertain as to how to proceed with missionary work, or if it was even desirable, early European Buddhists experimented with public talks, periodicals and pamphlets, translations of canonical texts, "services", hosting monks and what we would now call engagement, and unsurprisingly found it hard to make headway (Cox 2014b).

The fragile flowers of this first wave of Buddhist organizing in Europe grew within a wider popular counter-culture or social movement milieu that connected Buddhism, along with freethought, spiritualism and Theosophy, to more overtly political movements such as socialism, anarchism, feminism and pacifism, to moral reform movements such as temperance and vegetarianism (Gandhi 2006). In these contexts, broad orientations to internationalism, a world beyond imperialism, opposition to violence, and a better world could be expressed in what we now call religious rather than political terms, though at the time (when institutional religion was central to intra-European and imperial politics) these distinctions were not so clear-cut, and defection from existing denominational affiliations was often the key dividing line. 
Political conditions played a major role in enabling or constraining the formation of public Buddhist organizations. The long-term legacies of the wars of religion, secularist resistance to state churches, Kulturkampf and the formation of new nation-states produced very divergent religious politics from state to state, while mid-twentieth century authoritarianisms saw the end of Buddhist organization in Catholic Ireland, Nazi Germany and the Soviet Union alike. In Italy, despite long academic and cultural engagement with Buddhism (Pasqualotti 2012) and the high-profile Italian diaspora monk Lokanatha / Salvatore Cioffi (Deslippe 2013), no Buddhist groups were founded until long after the fall of fascism (Stortini 2012). Thus if the trauma of the First World War and the increasingly sharp conflicts around capitalist crisis and imperial expansion made a Buddhism understood as an ethical religion, free from property, class, nation, and war attractive, those same forces increasingly constrained the space for such an approach.

\section{Current research}

There is relatively little research on Buddhism in any single European country by contrast with Asia and North America. The variety of research languages, national histories and contexts (in terms of the legal situation of new religions, relationship to colonialism and hence migrant populations, the salience of religion within individual societies and the difference between Western and Eastern Europe) means that confident generalizations about Buddhism in Europe have to be limited to the most evident statistical and institutional points.

Much of the key work in the field, however, is conveniently located in a handful of instances, particularly the Journal of Global Buddhism and Contemporary Buddhism; the work of Martin Baumann in establishing and developing the study of Buddhism in Europe can hardly be overestimated. Baumann's (2001) category of "global Buddhism" chimes in some respects with Tweed's $(2011,2012)$ call for translocative analysis: in both cases the 
implication is a relativization of purely national-level analysis. A typical Buddhist group in Europe is linked both to one or more Asian centers of authority and to one or more European or North American organizational networks or centers. At least some more intensive retreats and training of teachers are likely to occur abroad, whether elsewhere in the global North or in Asia. Buddhism, in Tweed's sense, "flows" through Europe, and is only partially captured by a traditional focus on the national level.

\section{The growth of Buddhism in Europe}

If in absolute terms there is more European production of written material on Buddhism than ever before, the volume was already high in the later nineteenth century (Franklin 2008). The relationship between publication and practice is not linear, and the last 50 years have seen a strong shift from a bibliocentric approach, framed in the cosmological terms of European religious and philosophical thought, to a much more practice-oriented approach. In particular, meditation (for Pure Land and Nichiren traditions, chanting) has become a defining feature of "being Buddhist": as Carole Cusack (pers. comm.) suggests, a non-meditating Buddhist is like a lapsed Catholic ${ }^{2}$.

This is a relatively new development. It was not until the postwar period, as meditation teaching for the laity had become much more widespread across modernist Buddhisms in Asia, that the new "packages" of evening courses, urban meditation centers and short retreats spread across Western Europe. In this context, D.T. Suzuki's books, many first published decades earlier, became popular classics defining meditation as the essence not only of Zen but of Japanese culture, of spirituality or indeed humanity.

This second wave of Buddhist organizing developed in a rather different context from the first. With the end of empires, decolonization led to the typical European in Asia being a traveler in search of cultural difference rather than a colonist. Imperial chickens came home 
to roost in the form of Asian immigration, while Cold War conflicts led to Tibetan teachers in particular becoming refugees. Elsewhere in Asia, independence enabled a strong identification of Buddhism with various ethno-religiously defined nation-states.

If decolonizing wars in Asia and the ongoing threat of war in Europe continued to encourage adherence to Buddhism as a "religion of peace", the earlier anti-capitalist reading declined with the institutionalization of welfare states and state socialism in Western and Eastern Europe. From the 1970s, ecological concerns increasingly meshed with romantic readings of traditional Asian Buddhist cultures as offering alternatives to breakneck industrialization and urbanization, and in some countries to an anti-rationalism or antiintellectualism tied to the shift from cosmology to practice. In countries like West Germany and Italy, such readings remained suspect until much later, because of their resonances with fascist rhetoric and the actual fascist dalliances of Buddhist sympathisers like Giuseppe Tucci or Heinrich Harrer.

From the 1970s, Buddhism has increasingly become an established religious identity within European countries, firstly with the arrival of substantial migrant groups from traditionally Buddhist countries and secondly as European converts struggle with how to bring up their children (Cirklova 2012, Thanissaro 2014). Both points need to be qualified: smaller migrant groups, and those outside major cities, typically lack the resources to construct their own religious centers and may be thrown back on family practice or convertrun centers.

Conversely, only some converts understand Buddhism as religion and of those only some are keen to transmit it, while others take an "Anabaptist" position, leaving their children free to choose as adults. This follows an earlier line of interpretation in which Buddhism was often an alternative to European institutionalization of religious affiliation. However, identity is not only a personal matter: in many European countries state recognition of a religion has 
legal and cultural effects (representation in education, media or censuses; rights around marriage, funerals, hospital or prison visits etc.) and Buddhist umbrella associations have often been formed for this reason, thus constructing public identities comparable to other religions (Baumann 2007).

\section{Statistical indications}

For the mid-1990s, Baumann (2001, 21) estimated c. 900,000 Buddhists in Europe, 650,000 of Asian ancestry and the rest (almost all) converts. The largest populations were in France (forming $0.6 \%$ of the total population), Britain and Germany, with most in Western Europe and a typical contribution of $0.1 \%-0.2 \%$ of the population.

More recently, Baumann noted that "informed guesses" for Europe's Buddhist population suggest one or two million $(2007,351)$. However, scholars have increasingly questioned how far individuals can usefully be categorized as "Buddhist" or "not-Buddhist", particularly but not only in relation to converts (Mathé 2010, $523-4$ ) - and noted the multiple meanings of religious self-identifications in censuses (Macourt 2011).

It is clear that numbers of both converts and Buddhists of Asian ancestry have grown, although the proportion of "second-generation converts" is not as high as might be imagined. Buddhism has grown in new contexts such as Scandinavia (Borup 2008), Ireland and post1989 Eastern Europe. Finally, the once-traditional "top-down" approach associated with census counts and the study of institutional organization has increasingly been complemented by research on Buddhist practitioners at local level (Kennedy 2007, Waterhouse 1997), highlighting the diversity of individual orientations and available traditions. 


\section{European traditions of Buddhism}

\section{Europe's indigenous Buddhists}

Europe has one indigenous Buddhist tradition, that of the Kalmyks, Buriats and Tuvans, ethnicities within the Russian Federation practicing Mongolian forms of Tibetan Gelugpa. Kalmykia is technically within Europe (NW of the Caspian Sea) while Buryatia and Tuva lie near Lake Baikal in Siberia (see Sabirov 2012 on the Buriat experience). However, both Kalmyk and Buriat migrants in St. Petersburg attended the Datsan Gunzechoinei temple, established by Agvan Dorzhiev and operating between 1913 - 1933 (Ostrovskaya 2004). The eccentric Estonian / Latvian Buddhist and neopagan Karlis Tennison (Brother Vahindra), linked to Dorzhiev, wrote and translated on Buddhist topics from c. 1910 - 1930 (Talts 2008). A substantial school of academic Buddhist Studies existed in St Petersburg from the mid-nineteenth century until 1936, with a particular interest in these ethnicities, while refugee Kalmyks operated temples in Belgrade between the 1920s and the 1940s (Baumann 2002: 91). Since the later 1980s indigenous Buddhism has revived both in the various post-Soviet republics and among migrant communities.

\section{Asian-oriented Buddhisms with a European base}

A number of significant Buddhist traditions, while oriented to Asian contexts, are sufficiently well-established in Europe as to be discussed as manifestations of European Buddhism and highlight some of the complexities. The Association Zen Internationale, founded in 1970 by the Soto Zen teacher Taishen Deshimaru as the "Association Zen d'Europe,"3 is Europe's largest single Zen tradition, with about $11 \%$ of centers (Koné 2001, 146). Based in France and with active groups across Western Europe and beyond, the AZI has a strong institutional link to Japanese Soto Zen but its own self-contained organization, with tensions around the degree of Europeanisation and issues of authority. 
By contrast, European branches of Soka Gakkai International (SGI) are part of a globally-organized institution, balancing a very particular situation as a "new religious movement" within Japan with relatively high convert numbers abroad, and a commitment to political engagement (Seager 2006 ${ }^{4}$ ). In 2007, about half of all European SGI members were in Italy (Barone 2007, 118).

If the constellation of organizations - Plum Village monastery, the Order of Interbeing and the Unified Buddhist Church - founded by French-based Vietnamese monk Thich Nhat Hanh are apparently in a similar organizational situation to AZI as a European foundation (representing about $6 \%$ of European Zen centers in 2001: Koné 2001, 146) within a well-established Asian tradition, their balancing act is as complex as SGI's in that it includes substantial Vietnamese refugee and migrant populations as well as Nhat Hanh's role as global Buddhist celebrity author.

A final example in this category is Theravada traditions which pride themselves on their orthodoxy and tradition. Despite long struggles in the attempt to establish a bhikkhusangha in Britain (Skilton 2013), Thai Forest Tradition teacher Ajahn Chah revived the Hampstead Buddhist Vihara in part through the traditional alms round as a means of demonstrating moral commitment; developing this sangha also involved innovation in the introduction of a bhikkhuni-sangha (nuns' order) and an anagarika (celibate layperson) status (Bell 2000).

\section{New claims to religious charisma in Europe}

New organizational foundations, even situated within Asian lineages, require a Weberian charismatic founder to legitimize their new departure. The locus classicus for Europe might be the controversial Diamond Way, founded by Danish lama Ole Nydahl as an original layoriented departure within the Kagyupta tradition. Scherer $(2009,25)$ estimates of 15,000 
members and 70,000 sympathizers for this tradition, which is perhaps the single largest Buddhist tradition in East and Central Europe. Its originality is underlined by allegiance to the "minority" claimant to the throne of the $17^{\text {th }}$ Karmapa (and headship of the Karma Kagyus), Trinley Thaye Dorje, in opposition to the claimant supported by the $14^{\text {th }}$ Dalai Lama, while in terms of content Diamond Way is best described as neo-orthodox (Scherer 2009, 2011).

The effect of dissociation from the dominant trend in Tibetan Buddhism-in-exile is to enhance the relative significance of the international organization (Scherer 2011: 88). Similar dynamics are evident in relation to the New Kadampa Tradition (NKT), which stresses its independence from other Gelugpa schools and calls for a return to the Gelugpas' historical roots (Kay 2004). Such tensions not only combine conflicts over institutional authority with the complex relationship between Asian lineages and European organizations; they too, perhaps particularly for Tibetan Buddhist converts, involve a wider conflict over charisma and how Buddhism is perceived in the wider society or by less institutionalized Buddhists, notably in relation to the Dalai Lama as global Buddhist celebrity but often misunderstood as speaking for Buddhism as a whole. To much of the rest of the Buddhist world, NKT is famous for its position on the Shugden controversy - its support of a regionally-based deity whom the $14^{\text {th }}$ Dalai Lama has sought to remove from Tibetan practice ${ }^{5}$

A different kind of innovation appears in Houn Jiyu-Kennett's Order of Buddhist Contemplatives. While in some respects this shares the pattern of the AZI or Thich Nhat Hanh in that Jiyu-Kennett was an authorized Zen teacher setting up a new organization in the West (initially the US and UK), her teaching was more innovative (Kay 2004), adopting elements of high-church Anglican dress, music and ritual and emphasizing gender equality. 
New beginnings with European founders

The Triratna Community (previously Friends of the Western Buddhist Order) and Arya Maitreya Mandala (AMM) represent explicitly synthesizing forms of Buddhism. The German-Bolivian Ernst Hoffmann (Lama Govinda) founded the AMM as a new Buddhist order in Darjeeling in 1933 with the participation of Buddhists from various countries and traditions. The order, brought to Europe from 1952 (Berlin) onwards, encourages exploration of the different schools of Buddhism and its members are not monks in the sense of following particular lifestyle rules.

Similarly, Londoner Dennis Lingwood (then-bhikkhu Sangharakshita) founded the Western Buddhist Order and its "Friends" in London (1967-68) on a basis of synthesizing doctrines and practices from Theravada, Mahayana and Vajrayana and structured around a lay order. Both Lama Govinda and Sangharakshita drew strongly on European romanticism in their exegesis (Baumann 2012, 127 - 9). Both traditions have a long-standing Asian presence (in Singapore, Vietnam and India for the AMM; particularly among Dalit Buddhists in India for Triratna) and in Europe remain most strongly represented in their home countries of Germany and Britain respectively, albeit with branches elsewhere.

\section{Beyond traditional Buddhism?}

Perhaps the most characteristically European traditions of Buddhism, however, are not formal traditions in this sense. They follow a much wider trend in European religion - away from what in a Christian context would be denominational religion towards individualized forms of religion, attempts to separate "spirituality" (personal practice and experience) from "religion" (institution and doctrine), projects of dissolving religion into everyday life or the wider society, and ecumenical or synthesizing forms. In a Europe where traditional religious 
practice and conventional religious institutions are on the decline, it is unsurprising if most (successful) religious innovators do not simply seek to recreate past institutional forms.

\section{Night-stand Buddhists}

One long-standing tradition derives from Theosophy: Annie Besant's 1890s claim that the Theosophical Society represented the true, "esoteric Buddhism" was more powerful than Charles Pfoundes' arguments - despite the latter's knowledge of Japan and formal ties to an Asian Buddhist organization (Bocking et al. 2014). Theosophy's representation of Buddhism as simultaneously compatible with many other kinds of belief and a deeper, older and more arcane spirituality chimed with much of its representation in Victorian popular culture (Cox 2013: ch 3; Franklin 2008).

Both in conscious New Age contexts and in looser forms of popular spirituality, this usage of Buddhism as a basis of spiritual legitimation unconstrained by any close familiarity with Buddhist doctrine and practice remains widespread in Europe today, in ways which cannot be tightly quantified but whose intellectual and cultural origins can be traced to Theosophy among other sources (Heelas 1996). To take one example, some of the many Buddha statues sold in Europe today are bought and displayed by people who do not see themselves as exclusively Buddhist, but nonetheless "read" the image as having a spiritual or psychological meaning, not simply an aesthetic or intercultural one. On a more medieval note, the widespread practice of spuriously attributing uplifting or inspiring quotes to the Buddha $^{6}$ indicates something of the same reference to Buddhism within a looser and vaguer popular religiosity. As Heelas and Woodhead (2005) show in their in-depth study of the English town of Kendal, such experientially-oriented, personal spirituality is significant for a substantial proportion of the population of one of Europe's less conventionally-religious societies. 
Tweed's (2003) arguments about the significance of "night-stand Buddhists," with some sympathy for Buddhism but not embracing it exclusively or fully, point to a somewhat better informed, but selective, engagement with Buddhism, whose statistical significance he demonstrates for France. My own research on Ireland bears out Tweed's conclusions: exclusive and committed members of particular Buddhist organizations are a smaller group than those who identify as Buddhist without a strong affiliation or a consistent practice, who in turn are a smaller group than the wider population who sympathize with Buddhism and draw selectively on Buddhist ideas, practices or imagery (Cox 2013: ch. 7).

\section{Creolization}

Some of this, no doubt, responds to histories of sectarianism, external intolerance or internal control within religions established in Europe, articulating a "spiritual-but-not-religious" position which consciously resists any doctrinal orthodoxy or institutional affiliation. However, it is long since most Europeans (outside of countries like Poland, Ireland or Greece and some recent migrant groups) found themselves trapped in such religious contexts. The 250-year long conflict between religion and secularism, within religion between liberal and fundamentalist positions, and the encounter between different religions (not simply different Christian denominations) is more significant for how most Europeans experience religion.

One particular manifestation of this is in religious creolizations involving Buddhism. Already in the nineteenth century, Buddhist meditation was identified as a particular strength of "the East"; mental science in opposition to Western mastery of physical science (Crosby 2013). As liberal religion in the West shifted its emphasis from dogma, liturgy and ecclesiastical organization to personal experience and the inner life of the laity, meditation practices appeared as filling a significant gap. 
In the 1950s and 1960s, dialogue between French Jesuits and Japanese Zen practitioners explored the possibility of explicitly importing meditation practice within a Christian context. The German missionary Hugo Enomiya-Lassalle is one of the most significant figures in this transmission (Koné 2001, 145). This option was frowned upon under Pope John Paul II and then-Cardinal Ratzinger as Prefect of the Congregation for the Doctrine of the Faith, ushering in a period where Catholics often explored Buddhist practices without acknowledging, or even realizing, their origins. More generally a growing use of Buddhist-derived meditation within Christian contexts, consciously or unconsciously, appears in the liberal wings of various Christian churches and on a popular level; if these are not Buddhist traditions in an unambiguous sense, they are certainly deserving of research. Koné (2001, 146) estimates centers practicing Zen in a Christian setting as representing about $10 \%$ of the total and being mostly represented in Germanic and Scandinavian countries.

\section{Secular Buddhism}

The encounter between religion and secularism also shapes Europe's present-day formations of Buddhism. Since U Dhammaloka (Turner et al. 2010) in 1900, some Buddhists writing in English have argued that Buddhism is not vulnerable to the intellectual critiques levelled at Christianity; while a substantial proportion of the Buddhist traditions first imported westwards adopted a "Protestant Buddhist" approach which attempted to remove the mythological and ritualistic elements that might make it vulnerable to such critique.

Often, too, this "Protestant" approach was understood as removing culturally-specific accretions; logically, it seemed, a Buddhism for Westerners would be modern, rationalistic and scientific. "Secular Buddhism", a consciously non-religious form of Buddhism organized around mindfulness practices derived mostly from Burmese vipassana, and the related terms "secular mindfulness" and "mindfulness-based" therapies, form a family of related 
approaches which together constitute a European (and North American) Buddhist tradition of particularly recent origin (Higgins 2012; see the special issue of Contemporary Buddhism 12.1, 2011 on mindfulness). As with creolization, "night-stand Buddhists" and the New Age, these traditions are defined by relativizing or questioning their "Buddhist" characteristics without - in most cases - denying them altogether: the legitimacy and authority conferred by the reference to Buddhism (and Asia) is such that it takes the overriding power of the Catholic magisterium or natural-scientific peer review to force its complete abandonment.

\section{Engaged Buddhism}

In some ways, secular mindfulness represents an ultra-modernist Buddhism, taking modernism's emphasis on practice to its logical conclusion. Much the same could be said for engaged Buddhism, although here the practice may not be meditative. In engaged Buddhism, the reference to Buddhism is fundamental to the tradition's existence as separate from the wider world of secular social movement activism.

Engaged Buddhism is not a European invention (the term - apparently coined by Thich Nhat Hanh by analogy with French "engaged intellectuals" - has European roots); however it has a particular significance in Europe (and North America). In many Asian Buddhist contexts, the sangha is a well-established, inherently political institution, whether in the shape of Sinhalese nationalism or the Tibetan diaspora. The pan-Asian Buddhist revival of the late nineteenth and early twentieth centuries was a major contribution to anti-colonial movements in several countries, a fact obscured by representations of engaged Buddhism in Asia which select those forms of Buddhist politics most congenial to a Western Buddhist audience (Queen and King 1996) and thus imply that other Asian Buddhists are politically passive, perhaps "changing themselves" rather than "changing the world". 
Engaged Buddhism in the West is distinctive not in being political but rather in its presence within convert contexts where Buddhist institutions lack the kind of power within the community or relationship to the state that make them de facto political fields in much of Asia. Since there are many other, larger and more politically effective, spaces where Europeans can engage in politics, its practical definition is for those who wish to engage in politics as Buddhists, with other Buddhists or in a religiously-defined context (such as interfaith activism). It can therefore be seen as a (non-exclusive) Buddhist tradition, since its practitioners must simultaneously engage in discourses and boundary-defining activities that legitimate its Buddhist character and, often, articulate what is specifically Buddhist about the practices involved (for example, meditating in public, acts of non-violent civil disobedience or public statements on behalf of Buddhist bodies).

In a wider sense, aspects of Buddhist practice and organization within different European traditions are sometimes politicized in ways compatible with the engaged tradition. This can include official organizational initiatives, for example around alternative approaches to work (Baumann 1998) and internal challenges, for example around gender and sexuality (Munt and Smith 2012). Such developments within European traditions almost certainly affect more Buddhists in Europe than overtly engaged Buddhism.

\section{Conclusion}

This chapter has briefly sketched Buddhism's arrival in Europe before discussing various different kinds of European tradition: indigenous Buddhists; Asian-oriented Buddhisms with a particular European base; new claims to religious charisma founded in Europe; new beginnings with European founders; and various forms of "fuzzy religion" with Buddhist components. This short survey bears out Tweed's (2011) understanding of religion in terms of flows; or, put more historically, Buddhism's recent flowering in Europe came during a 
time of historically weak religious institutionalization and boundary formation which do not favor the formation of strongly-defined traditions but rather enable a series of flows which are often hard to capture in statistical, institutional or doctrinal terms.

Like fusion restaurants, most European traditions make claims for Asian origins but on European terms. Some of the "dishes" served might be immediately recognizable to Asian modernists (in some cases even to traditionalists); some use the same recipes in Paris and New York; and some owe more to the religious cuisine of a particular, European-based figure. A typical diner, perhaps, is more concerned with the taste of the food (or practice) than with its history, but nonetheless values the belief that Asian flavors are being served in a European way.

\section{Bibliography}

Almond, Philip. 1988. The British Discovery of Buddhism. Cambridge: Cambridge University Press.

Barone, Carlo. 2007. “A Neo-Durkheimian Analysis of a New Religious Movement.” Theory and Society 36.2: $117-140$.

Baumann, Martin. 1997. "Culture Contact and Valuation.” Numen 44.3: 270 - 295.

Baumann, Martin. 1998. "Working in the Right Spirit." Journal of Buddhist Ethics 5: 120 143.

Baumann, Martin. 2000. "Buddhism in Switzerland". Journal of Global Buddhism 1: 154 159.

Baumann, Martin. 2001. “Global Buddhism”. Journal of Global Buddhism 2: 1 - 43.

Baumann, Martin. 2002. "Protective Amulets and Awareness Techniques". In Westward Dharma, edited by Charles S. Prebish and Martin Baumann: 51 - 65. Berkeley: University of California Press. 
Baumann, Martin. 2007. "Ecumenicism and intra-Buddhist activities", in Encyclopedia of Buddhism, edited by Damien Keown and Charles Prebish: 306 - 307. Abingdon: Oxford.

Baumann, Martin. 2012. "Modernist Interpretations of Buddhism in Europe”, in Buddhism in the Modern World, edited by David L. McMahan: 113 - 136. Abingdon: Oxford.

Baumann, Martin. 2015. Review of Jens Schlieter et al (Hg.), Die zweite Generation der Tibeter in der Schweiz, 2014. Anthropos 110.1: 270 - 271.

Bell, Sandra. 2000. "Being Creative with Buddhism”. Journal of Global Buddhism 1: 1 - 23.

Bocking, Brian, Cox, Laurence and Yoshinaga Shin'ichi. 2014. "The first Buddhist Mission to the West." DISKUS 16.3: 1 - 33 .

Borup, Jørn. 2008. “Buddhism in Denmark”. Journal of Global Buddhism 9: 27 - 37.

Cirklová, Jitka. 2012. "Buddhism as a Value Source in the Course of New Identity and Lifestyle Formation in the Czech Republic". Contemporary Buddhism 13.2: 263 - 279.

Clarke, J.J. 1997. Oriental Enlightenment. London: Routledge.

Cox, Laurence. 2013. Buddhism and Ireland. Sheffield: Equinox.

Cox, Laurence. 2014a. "Buddhism in Ireland”. Etudes Irlandaises 39.2: 161-172.

Cox, Laurence. 2014b. "Inventing Buddhist Modernism". Paper presented to the "Asian Buddhism” conference, Kyoto University, Japan, December 12 - 14 .

Crosby, Kate. 2013. Traditional Theravada Meditation and its Modern-Era Suppression. Hong Kong: Buddha Dharma Centre of Hong Kong.

Deslippe, Philip. 2013. “Brooklyn Bhikkhu”. Contemporary Buddhism 14.1: 169 - 186.

Franklin, Jeffrey. 2008. The Lotus and the Lion. Ithaca: Cornell University Press.

Heelas, Paul. 1996. The New Age Movement. Oxford: Blackwell.

Heelas, Paul and Linda Woodhead. 2005. The Spiritual Revolution. Oxford: Blackwell.

Higgins, Winton. 2012. “The Coming of Secular Buddhism”. Journal of Global Buddhism 13: $109-126$. 
Humphreys, Christmas. 1937. The Development of Buddhism in England. London: Buddhist Lodge.

Kay, David N. 2004. Tibetan and Zen Buddhism in Britain. London: RoutledgeCurzon.

Kennedy, Andrew. 2007. "Reflections on Buddhism in Leeds". Contemporary Buddhism 5.2: $143-156$.

Koné, Alione. 2001. “Zen in Europe”. Journal of Global Buddhism 2: 139 - 161.

Lopez, Donald. 1998. Prisoners of Shangri-la. Chicago: University of Chicago Press.

Macourt, Malcolm. 2011. "Mapping the 'New Religious Landscape' and the 'New Irish'." In Ireland's New Religious Movements, edited by Olivia Cosgrove, Laurence Cox, Carmen Kuhling and Peter Mulholland: 28 - 52. Newcastle: Cambridge Scholars.

Mathé, Thierry. 2010. "Le développement du bouddhisme en contexte italien." Social Compass 57: $521-536$.

McMahan, David L. 2008. The Making of Buddhist Modernism. Oxford: Oxford University Press.

Munt, Sally R. and Sharon E. Smith. 2012. "Angels and the Dragon King's Daughter." Theology \& Sexuality 16.3: 229 - 258.

Ostrovskaya, Elena. 2004. "Buddhism in St. Petersburg". Journal of Global Buddhism 5: 19 65.

Pasqualotti, Giangiorgio. 2012. "Il Buddhismo nella cultura italiana.” Quaderni di cultura italiana 9: $31-70$.

Queen, Christopher and Sallie King. 1996. Engaged Buddhism. New York: SUNY Press. Sabirov, Rustam. 2012. "Buddhism in the Russian Republic of Buryatia". In Mongolians After Socialism, edited by Bruce M. Knauft and Richard Taupier. Ulaanbaatar: Admon, 235 248. 
Scherer, Burkhard. 2009. "Interpreting the Diamond Way". Journal of Global Buddhism 10: $17-48$.

Scherer, Burkhard. 2011. "Macho Buddhism". Religion and Gender 1.1: 85 - 103.

Seager, Richard. 2006. Encountering the Dharma. Los Angeles: University of California Press.

Skilton, Andrew. 2013. "Elective affinities". Contemporary Buddhism 14.1: 149 - 168.

Stortini, Paride. 2012. "La presenza del Buddhismo in Italia." Quaderni di cultura italiana 9: $71-102$.

Talts, Mait. 2008. “'The first Buddhist Priest on the Baltic Coast'”. Folklore: Electronic Journal of Folklore, 38: 67 - 112.

Thanissaro, Phra Nicholas. 2014. "Attitudes Deriving from Buddhist Nurture in Britain”. Journal of Buddhist Ethics 21: 728 - 759.

Turner, Alicia, Cox, Laurence and Brian Bocking. 2010. "Beachcombing, Going Native and Freethinking”. Contemporary Buddhism 11.2: 125 - 147.

Turner, Alicia, Cox, Laurence and Brian Bocking. 2013. "A Buddhist Crossroads". Contemporary Buddhism 14.1: 1 - 16.

Tweed, Thomas. 2000. The American Encounter with Buddhism 1844 - 1912. Bloomington: Indiana University Press.

Tweed, Thomas. 2003. "Who is a Buddhist?" In Westward Dharma, edited by Charles S. Prebish and Martin Baumann: 17 - 33. Berkeley: University of California Press.

Tweed, Thomas. 2011. "Theory and Method in the Study of Buddhism". Journal of Global Buddhism 12: 17 - 32 .

Tweed, Thomas. 2012. “Tracing Modernity’s Flows”. The Eastern Buddhist 43.1\&2: 1 - 22.

Waterhouse, Helen. 1997. Buddhism in Bath. Leeds: University of Leeds.

Weigelt, Frank. 2011. "From Chanting to Chán”. Pacific News 36: 20 - 24. 


\footnotetext{
${ }^{1}$ See the chapters in this volume by Brooke Schedneck and John Nelson.

${ }^{2}$ Weigelt (2011) shows that Vietnamese Buddhist groups in Switzerland are also making this shift, explaining a decline in traditional religious behaviour among the second generation by a lack of Vietnamese language skills. Vietnamese monks based in France and the US are thus being invited to teach meditation through English and French. Conversely, second-generation Tibetan immigrants in Switzerland are also abandoning traditional religious behaviour, but towards a more individualised understanding of Buddhism as an ethical philosophy for living (Baumann 2015). I am indebted to Michael Jerryson for these references.

${ }^{3}$ http://www.zen-azi.org/node/15, accessed March 232015.

${ }^{4}$ See Brooke Schedneck's chapter in this volume.

${ }^{5}$ See Abe Zablocki's chapter in this volume.

${ }^{6}$ See http://fakebuddhaquotes.com/.
} 